\title{
1. Introduction: acknowledging the complexities of post-conflict socio-economic justice
}

Structural inequality is deeply intertwined with the dynamics of civil war. Though political, psychological and cultural stimuli may drive the recourse to violence, it is conditioned by deeper socio-economic factors and pathologies of power that determine types of harm and who should suffer it. There is, therefore, a growing consensus in scholarship and policy implementation across numerous disciplines like peacebuilding, development and international relations that states emerging from noninternational violent conflict can only enjoy a just and sustainable peace if it is consolidated on the basis of economic and social development that meets the needs of the entire population. It is assumed that a peace agreement between belligerents will not endure in the long-term without attention to the basic human needs of individuals, distinct vulnerable social groups and society as a whole. To the extent that peace endures, it will prove illusory or hollow without attention to the everyday lives of those who live within its terms. As such, interveners in post-conflict states are increasingly oriented towards what is broadly described as 'positive peace', which requires attention not only to direct violence or conflict, but to structural and cultural forms of violence in the social and economic spheres which deny access to physical and social well-being. ${ }^{1}$ This trend is visible within peacebuilding, which manifests a definite, if imperfect and by no means uniform, migration from minimalist approaches oriented around the mere avoidance of conflict recurrence to a more maximalist approach that fosters transformation of the economic, social and political conditions that formed the background to war in the first place. Within the field of development, attention has begun to shift from narrow conceptions of economic growth to poverty alleviation, redress of horizontal inequalities and some measure of redistribution.

1 Johann Galtung, 'Violence, Peace and Peace Research' (1969) Journal of Peace Research 167. 
This consensus has found support within transitional justice in the last decade or so as the field expands beyond its traditional preoccupations with accountability, truth, reconciliation and non-recurrence. Over time, it has become apparent that forms of structural harm, those which occur where arrangements embedded in the political and economic organization of the social world damage people by preventing them from meeting their basic needs, have been rendered invisible in a discourse that elevated atrocities like genocide, crimes against humanity and torture over the less visceral slow violence of starvation, unemployment and poverty. The justifications for including issues of structural violence and inequality as integral components of transitional justice are pragmatic (peace can only be sustainable with attention to root causes), philosophical (an ethical preference for distributive justice and equity) and sociological (polls of survivor populations overwhelmingly demonstrate that socio-economic concerns trump the desire for criminal justice or truth in transitions). ${ }^{2}$ This re-direction of energies both conceptually and in practice has been somewhat piecemeal. It has proceeded gradually from the empirical awareness that while transitional justice mechanisms can acknowledge, condemn or punish acts that emerge in conflict, economic and social frameworks of inequality remain in place to diminish the quality of the peace in the present and jeopardize it in the longer term. This expansion began with isolated but widely cited calls by the likes of Rama Mani for a concept of redistributive justice within transitional justice to redress the inequalities that underlie social conflict ${ }^{3}$ and by UN High Commissioner for Human Rights Louise Arbour for a re-orientation of the field towards assisting the transformation of oppressed societies by exposing discriminatory practices and violations of economic, social and cultural rights before and during conflict. ${ }^{4}$ Increasingly, experts have argued that structural inequalities need to be incorporated within transitional justice policy as a means of redress for structural inequalities wherein a group (or groups) of people within a state endure an unequal status in relation to other groups which is perpetuated by consistently unequal attainment of rights and opportunities in relation to land, resources, opportunities and welfare. ${ }^{5}$ As the field transcends its legalist beginnings, justice is

2 Zinaida Miller, ‘(Re)Distributing Transition' (2013) 7 International Journal of Transitional Justice 370, 377.

3 Rama Mani, Beyond Retribution - Seeking Justice in the Shadows of War (Polity Press 2002).

4 Louise Arbour, 'Economic and Social Justice for Societies in Transition' (2007) 40 NYU Journal of International Law and Policy 1, 3.

5 A survey of these positions in found in the next chapter. 
understood less as accountability or punishment than as a set of general principles for allocating collective benefits, opportunities and burdens. This approach complements - and builds on - existing commitments to confront issues of injustice and subsistence harms that face marginalized groups like women, children, minorities and indigenous peoples. The emerging but strikingly unchallenged assumption is that transitional justice is a 'methodology for social transformation' in the broadest sense of the term. ${ }^{6}$

Transitional justice scholars and practitioners (as always, the discourses between the two are fluid and intertwined) increasingly call for transitional justice to 'actively reverse the systems and attitudes that discriminate and dehumanize' across the entire society ${ }^{7}$ and to bring economic and social needs to the foreground of its processes to address the root causes of conflict. ${ }^{8}$ Any gains of transitional justice might not be fully realized if the structural causes of repression or conflict are left unaddressed. ${ }^{9}$ Scholars now routinely contend that addressing mass poverty should be recognized as an object of justice. ${ }^{10}$ The failures to analyse the structural underpinnings of violence, to critique noxious development policies or to promote redistribution mean that old grievances will inevitably transmute into new ones. ${ }^{11}$ These aspirations are imperative not only for the societies themselves, but for the continued relevance of transitional justice - the concept risks losing credibility unless it improves overall living conditions for citizens in the transitional

6 Sandra Nichols, 'Reimagining Transitional Justice for an Enduring Peace: Accounting for Natural Resources in Conflict' in Dustin Sharp (ed.), Justice and Economic Violence in Transition (Springer 2013) 203 at 211.

7 Matthew Mullen, 'Reassessing the Focus of Transitional Justice: The Need to Move Structural and Cultural Violence to the Centre' (2015) 28 Cambridge Review of International Affairs 462, 477.

8 Amanda Cahill-Ripley, 'Foregrounding Socio-Economic Rights in Transitional Justice: Realising Justice for Violations of Economic and Social Rights' (2014) 32 Netherlands Quarterly of Human Rights 183, 183.

9 Pablo de Greiff, 'Articulating the Links Between Transitional Justice and Development: Justice and Social Integration' in Pablo de Greiff and Roger Duthie (eds), Transitional Justice and Development: Making Connections (Social Science Research Council 2009) 28 at 33.

10 Ruben Carranza, 'Plunder and Pain: Should Transitional Justice Engage with Corruption and Economic Crimes?' (2008) 2 International Journal of Transitional Justice 310, 315.

11 Lisa Laplante, 'Transitional Justice and Peace Building: Diagnosing and Addressing the Socioeconomic Roots of Violence through a Human Rights Framework' (2008) 2 International Journal of Transitional Justice 331, 334. 
state. ${ }^{12}$ This trend should not be exaggerated - transitional justice still remains legalistic in orientation and rooted in a civil and political rights-based framework at a policy level. ${ }^{13}$ However, to judge from recent literature, most notably in the International Journal of Transitional Justice and the Transitional Justice Review, energy is directed towards more transformative understandings of the concept. If the history of transitional justice demonstrates anything, it is that ideas current in theory generally transfer to policy, where possible. ${ }^{14}$ Indeed, some extant critiques of transitional justice's conservatism have been assimilated at the level of policy and practice, even if this is often superficial. ${ }^{15}$

This book specifically examines the prospects for transformative justice in the context of post-conflict societies. Chapter 2 examines this 'transformative turn' in detail. Though Teitel famously argued that in the present era of 'steady state' transitional justice, the field has become the normalized response to atrocity in post-conflict situations, ${ }^{16}$ much of the theorization of transitional justice's potential to address structural sources of poverty and inequality does not specifically address postconflict societies. Most scholarship in the area is pitched at a general level, describing aspirations for the field that apply with equal force in developed settler colonies, post-authoritarian states and states that have not undergone anything resembling transition, and so do not address the unique dilemmas of states emerging from internal armed conflict.

12 Rama Mani, 'Editorial: Dilemmas of Expanding Transitional Justice, or Forging the Nexus Between Transitional Justice and Development' (2008) 2 International Journal of Transitional Justice 253, 253-54.

13 See, for example, Guidance Note of the UN Secretary-General: United Nations Approach to Transitional Justice (2010) which maintains a traditional concern with corrective justice, albeit with some lip-service to root causes and violations of economic and social rights <http://www.unrol.org/files/TJ_ Guidance_Note_March_2010FINAL.pdf > accessed 20 July 2016, or the fourlimbed mandate of the Special Rapporteur on the Promotion of Truth, Justice, Reparation and Guarantees of Non-recurrence which is arguably consistent with an expanded transitional justice but underplays any desire to deal with structural issues (see the Rapporteur's Report A/HRC/21/46 of 9 August 2012).

14 Padraig McAuliffe, 'From Molehills to Mountains (and Myths?): A Critical History of Transitional Justice Advocacy' (2011) 22 Finnish Yearbook of International Law 85.

15 Dustin Sharp, 'Interrogating the Peripheries: The Preoccupations of Fourth Generation Transitional Justice' (2013) 26 Harvard Human Rights Journal 149, 177.

16 Ruti Teitel, 'Transitional Justice Genealogy' (2003) 16 Harvard Human Rights Journal 69. 


\section{DEFINING 'POST-CONFLICT'}

'Post-conflict' is a highly imprecise concept, but it generally refers to the situation pertaining when an armed conflict comes to an end. There are three main ways armed conflicts reach this point: (1) a negotiated settlement among the main protagonists in the absence of an outright victor, (2) victory by one side, or (3) the petering out of conflict without agreement or victory for any side. Only negotiated settlements are examined in this book, for reasons which are described below. The most common feature of a negotiated end to conflict is a peace agreement. Peace agreements are examined in greater detail in Chapter 3, but for now it will suffice to note that the typical agreement will, inter alia, reform or create $a b$ initio the previously contested political rules by which society will be governed, provide rules for demobilization and security sector reform, deal with return of internally displaced persons, refugees and land, and elaborate forms of transitional accountability or reconciliation. Of course, even in this context the term 'post-conflict' is problematic, suggesting as it does an uncomplicated trajectory from violent insecurity to pacific stability that is belied by residual violence and spikes in criminal activity. There are no fixed boundaries between conflict and post-conflict, though there is a psychological element to it insofar as a consensus exists among antagonists, society at large and peacebuilders that there is peace, or at least that a new, non-violent political dispensation prevails.

Certainly, a settlement alone cannot be equated with 'post-conflict'. Significantly more peace agreements are signed than are ever put into practice. Depending on how and when war and recurrence are codified, anything from a quarter to a half to over four-fifths of intrastate peace settlements break down in the following five to ten years. ${ }^{17}$ There are many reasons for this. In some cases, negotiations and even agreements may not be directed towards ending a conflict as belligerents conceal 'devious objectives' whereby they use the settlement process as a breathing space to regroup and prepare to resume fighting. They may do

17 For example, Astri Suhrke and Ingrid Samset, 'What's in a Figure? Estimating Recurrence of Civil War' (2007) 14 International Peacekeeping 195, citing around 23 per cent; Philip Martin, 'Coming Together: Power-Sharing and the Durability of Negotiated Settlements' (2013) 15 Civil Wars 332, 334 citing one-half; Michael Brown and Marie-Joëlle Zahar, 'Social Cohesion as Peacebuilding in the Central African Republic and Beyond' (2015) 10 Journal of Peacebuilding and Development 10, 10 citing 85 per cent not lasting beyond the five-year mark. 
this to enhance their status domestically before their own constituents, to legitimize themselves in the international area as legitimate recipients of the resources peace processes bring, or as a means of testing each other's will. ${ }^{18}$

The problem of domestic insincerity is compounded by that of international callowness. Widely reported civil wars present the international community with the choice of walking away and allowing antagonists to fight it out to the bitter end, or mediating between the warring sides to bring it to a close. In an era where the established norm is to resolve violent conflict through negotiation rather than through military force, the UN and third-party states face strong incentives to mediate - and to have something to show for it. In such an environment, there is a perception that a bad agreement may be better than none at all. As Weinstein argues, this leads to premature settlements that 'freeze unstable distributions of power and to provide a respite from hostilities for groups that are intent on continuing the conflict when the international community departs'. ${ }^{19}$ In such circumstances, glorified truces that temporarily end conflict but omit authoritative stipulations regarding the future exercise of political power or quick-and-easy false peaces based on good faith that eschew tough choices like disarmament or genuine power-sharing, are the norm. A good example is Liberia after 1989, which ran through eleven peace agreements and approximately twenty ceasefires before the Accra Comprehensive Peace Agreement in 2003. Agreements such as those before Accra are replicated in many conflicted states and either neglect to establish credible minimum conditions for peace or leave ample space for opportunistic interpretation by either side, accounting for a large proportion of failed peaces. Some parties sign agreements not for short-term mutual security but in the strategic belief they can out-manoeuvre opponents and secure war aims within the context of the agreement. If this fails, or indeed if it succeeds, one of the parties may return to war. Some agreements are entered into with greater goodwill but fail because they are vague, leave key matters relating to the belligerents' war aims or identity undecided (e.g. Angola's Lusaka Protocol, which left military issues to be decided after signing) or

18 Oliver Richmond, 'Devious Objectives and the Disputants' View of International Mediation: A Theoretical Framework' (1998) 35 Journal of Peace Research 707.

19 Jeremy Weinstein, 'Autonomous Recovery and International Intervention Comparative Perspective' (Center for Global Development Working Paper 57, 2005) 9 <http://www.cgdev.org/files/2731_file_WP57.pdf> accessed 20 July 2016. 
have faulty implementation mechanisms due to state weakness (e.g. Mali's Tamanrasset Accords). Others are signed while fighting still continues in largely undiminished form (e.g. DR Congo's 2003 peace agreement), see incomplete fulfilment of undertakings (e.g. the LinasMarcoussis Peace Accord in Côte d'Ivoire) or are jeopardized by spoilers who use violence to undermine the peace or force their way into it (e.g. Jonas Savimbi in Angola or Foday Sankoh in Liberia). It is for these reasons that multiple bites of the cherry may be needed for an enduring peace.

It is to contexts where these pitfalls are avoided or where that final bite of the cherry has been taken that the titular phrase 'post-conflict' refers. The context for this book is the aftermath of reasonably successful settlements where military circumstances are ripe for resolution, where the peace agreement comprehensively addresses key grievances, initiates some form of inclusive power-sharing, and where the parties can credibly commit to abide by the terms. This includes ostensibly bad or incomplete peace agreements whose problems can be mitigated by peacebuilders or implemented forcefully by adversaries as their relationship grows more trustful. A good example of the type of context to which this book refers would be El Salvador's 1992 peace agreement, which provided for rebel disarmament and integration into the national military, land redistribution, dissolution of military intelligence and new elections. While by no means a solution to the roots of conflict, it provided a platform for sustainable peace and could potentially have opened the door to wider transformation. The sorts of post-conflict state this book refers to are the likes of Liberia, Nicaragua, Mozambique, El Salvador, Namibia, Sierra Leone, Nepal, post-Ta'if Accord Lebanon and Guatemala, where protagonists agree to pursue a definitive settlement. If peace is ever to occur in states like Libya, Yemen or even areas of Nigeria over-run by Boko Haram, then settlements of this sort will be indispensable in the absence of victories for one side. Of course, mere signing of an agreement would be an unacceptably short-term definition of 'post-conflict'. Even apparently comprehensive agreements break down due to state weakness and spoiler problems in the years following an agreement. Some even argue that ten-to-fifteen years need to pass in order to determine if a peace will last, but this is too long-term a view for the purposes of this book. Consequently, this book adopts Ingrid Samset's conventional understanding that a state is post-conflict if no new conflict emerges in the aftermath of a war for two-to-three years afterwards. ${ }^{20}$ Of course,

20 Ingrid Samset, 'Building a Repressive Peace: The Case of Post-Genocide Rwanda' (2011) 5 Journal of Intervention and Statebuilding 265, 268. 
peacebuilding and transitional justice activities will generally begin before this time has elapsed, so in a sense there is an unavoidable element of retrospective validation to this approach.

This generic definition of post-conflict is open to the valid complaint that there is no singular, homogenous post-conflict ecology, but rather many different types. This vacuous empiricism would exclude any possibility of categorization. However, as Chapters 3 and 4 go on to argue, there are some standard dilemmas and opportunities that face peacebuilders and transitional justice practitioners in the aftermath of conflict. Though not all states emerging from war face the same challenges, enough of them share a threshold similarity in the nexus among context, opportunity and strategies to justify the classification of 'post-conflict'. Above all, the antinomy of war to peace manifests the traditional transition paradigm of a "normative shift in the principles underlying and legitimating the exercise of power', ${ }^{21}$ plus at least some redistribution of that power. The transition from war to this type of negotiated peace is one that at least in theory offers opportunities 'not only for returning to a previous state of order but for deeply reforming it and dismantling old structures of economic crime, structural violence, and oppression', ${ }^{22}$ albeit tempered with a judicious concern for stability.

Thus, this book does not address states where the end of conflict was the product of victory by one side or the petering out of conflict without agreement or victory for any side. As regards victories, around one-third of civil wars since 1945 have ended in military victory for one side. ${ }^{23}$ The peace that results from settlements imposed by the victor lasts 170 per cent longer than negotiated peace, ${ }^{24}$ largely because the victors gain full control of the state while the defeated side lacks the strength to fight back or is aware of the likelihood of repeated defeat if they did. Although this coerced stability would in theory allow the government the power to undertake thoroughgoing justice, a government (re)established via raw power generated through military ascendancy has little incentive to

21 Ruti Teitel, Transitional Justice (Oxford University Press 2000) 213.

22 Kora Andrieu, 'Dealing with a "New" Grievance: Should Anticorruption Be Part of the Transitional Justice Agenda?' (2012) 11 Journal of Human Rights 537, 538.

23 Christoph Zürcher, Carrie Manning and Kristie Evenson, Costly Democracy: Peacebuilding and Democratization after War (Stanford University Press 2013) 38.

24 Philip Roeder, 'Power Dividing as an Alternative to Ethnic Power Sharing' in Donald Rothchild and Philip Roeder (eds), Sustainable Peace: Power and Democracy after Civil Wars (Cornell University Press 2005) 51 at 80. 
bargain over changing pre-war institutions or distributions of wealth/ opportunity or to accommodate differences. Few characteristics of the polity or society are altered, and exclusion rather than inclusion tends to be the norm, even if sometimes concessions - even a measure of power-sharing - are granted to losing sides if it means avoiding prosecuting war to the bitter end. In wars where the state emerges victorious like Sudan (Darfur), Uganda and Sri Lanka, nothing cognisable as transition occurs in any case. As Kurtenbach and Meyler put it, strong sitting governments after war 'avoid deep-cutting reforms enshrined in constitutions while those with limited bargaining power give in much more easily'. ${ }^{25}$ Wars that ended in a one-sided military victory do not need the sort of international mediation that could incentivize reforms for governments, and they tend to have a much lighter peacebuilding footprint - if any. In addition, the nature of the polity differs from that which follows a peace agreement. Negotiated settlements tend to introduce some sort of democratic settlement premised on power-sharing (though the democratic nature of this dispensation should not be exaggerated), while military victory tends to be less supportive of representative government. ${ }^{26}$ These states often gravitate towards what is called 'dominant-power politics' with limited political space and some contestation, but overall one political grouping dominates the system in a manner that makes alternation of power improbable. ${ }^{27}$ Power-sharing governments after peace agreements, by contrast, offer potentially greater scope for revision of socio-economic structures. Victory for insurgent forces also results most usually in one form of autocracy being replaced by another. ${ }^{28}$ As familiar examples like Ethiopia, Rwanda and Côte d'Ivoire make apparent, transitional justice is apt to reinforce the power of the stronger party victors' justice and purges directed at the loser of the conflict tends to trump reconciliation or toleration (to say nothing of economic transformation), while the victor's ability to impose their narrative of the conflict obviates the need for truth commissions to consider cause, responsibility

25 Sabine Kurtenbach and Andreas Mehler, 'Introduction: Institutions for Sustainable Peace? Determinants and Effects of Institutional Choices in Divided Societies' (2013) 15 Civil Wars 1, 3.

26 Mehmet Gurses and T. David Mason, 'Democracy Out of Anarchy: The Prospects for Post-Civil-War Democracy' (2008) 89 Social Science Quarterly 315 .

27 Thomas Carothers, 'The End of the Transition Paradigm' (2002) Journal of Democracy 5, 11-12.

28 Larry Diamond, 'Promoting Democracy in Post-Conflict and Failed States: Lessons and Challenges' (2006) 2 Taiwan Journal of Democracy 93, 96. 
or reform. It is not, of course, beyond the realm of possibility that the government or rebel winners might pursue genuine transitional justice or transformation of structures that benefit them in a more egalitarian manner, but the context in which it would happen is so different from the paradigm of a negotiated peace that this book cannot presume to speak to it.

The same applies to those wars that peter out. Depending on how wars are coded, as many as 40 per cent of civil wars simply ebb away, dropping below the threshold at which an armed conflict is classified, perhaps reflecting a mutual acceptance that a conflict has ended that may be surmised from the simple fact that hostilities are no longer occurring. ${ }^{29}$ A good example is the Peruvian civil war, which ended not by negotiations but by the gradual decrease of conflict-related deaths to a literal handful by 2001.30 Indeed, in states with low levels of formal institutionalization where war, political violence and displacement are the norm, the concept of 'post-conflict' may not even be that useful. ${ }^{31}$ Consequently, these 'no war, no peace' situations are also excluded from the book.

\section{THE IMPACT OF STRUCTURAL AND POST-CONFLICT VARIABLES}

As Bhuta argues, the humanitarian urge to better the world fosters a propensity to see the world as 'limitlessly malleable' through political effort. ${ }^{32}$ This propensity is exaggerated in the context of post-conflict transition, which tends to be viewed as a 'brief, but significant window for substantial institutional change ... and in that short-lived post-conflict moment, a new equitable political and economic order seems entirely possible. ... that privileges public interests and aims for a more equitable

29 See generally Joakim Kreutz, 'How and When Armed Conflicts End: Introducing the UCDP Conflict Termination Dataset' (2010) 47 Journal of Peace Research 243.

30 Charles Call, Why Peace Fails: The Causes and Prevention of Civil War Recurrence (Georgetown University Press 2012) 178.

31 Charles Call and Susan Cook, 'On Democratization and Peacebuilding' (2003) 9 Global Governance 233, 240-41.

32 Nehal Bhuta, 'Democratization, State-Building and Politics as Technology' in Brett Bowden, Hillary Charlesworth and Jeremy Farrall (eds), The Role of International Law in Rebuilding Societies after Conflict: Great Expectations (Cambridge University Press 2009) 38 at 60. 
distribution of resources' ${ }^{33}$ The transformative turn in transitional justice is similarly guided by the belief that with superior knowledge, more openness to the views of ordinary people and deeper engagement, transitional justice can and should achieve more comprehensive and extensive transformation of the domestic structures of distribution. It is assumed that a transition from violence offers a rare period of rupture that affords opportunities to 'reconceive the social meaning of past conflicts in an attempt to reconstruct their present and future effects'. ${ }^{34}$ Transitional justice scholars and policy-makers who share and urge this transformative impulse display an optimism that transitional justice can 'transcend' political conflict or that it enjoys a form of 'performative force' to impose new boundaries on the meaning of political reform. ${ }^{35} \mathrm{In}$ effect, this assumes or at least risks assuming that there are virtually no preconditions that preclude the possibility of societal transformation. There is an apparent conviction that the same aspirations for transformation are realizable through transitional justice in any number of states, even if not to the same extent. This type of logic has been applied to truth commissions and trials, which are understood to produce the same effects in wildly varying contexts, even where the most cursory glance at their historical record shows they are critically shaped by the ecology they apply to. As De Greiff puts it:

New contexts of application generate new needs, yet the capacity to satisfy those needs in these novel contexts is simply attributed to the same measures, abstracting from institutional and other kinds of preconditions for their successful implementation, and without any careful analysis of their functional adequacy for the satisfaction of those needs. ${ }^{36}$

The problem with undifferentiated treatments of post-conflict states is that dilemmas are presented as generic and solutions as open-ended. The

33 Christine Cheng, 'Private and Public Interests: Informal Actors, Informal Influence and Economic Order after War' in Mats Berdal and Dominik Zaum (eds), Political Economy of Statebuilding: Power after Peace (Routledge 2013) 63 at 63.

34 Daniel Aguirre and Irene Pietropaoli, 'Gender Equality, Development and Transitional Justice: The Case of Nepal' (2008) 2 International Journal of Transitional Justice 356, 357.

35 Catherine Turner, 'Deconstructing Transitional Justice' (2013) 24 Law and Critique 193, 201 and 200.

36 Pablo de Greiff, 'Transitional Justice Gets Its Own Encyclopedia: Vitamins or Steroids for a Developing Field?' (2013) 7 International Journal of Transitional Justice 547, 552. 
answer is always a better conceptualization of issues, more resources, improved attention, with the attendant risk of tautology - if transitional justice actors and domestic constituencies are willing to do everything that is necessary in the interests of transformative justice, then justice will be transformative. Advocates of a transformative approach make no attempt to calibrate justice interventions to the most salient political conditions, nor do they question whether there are any preconditions that preclude transformation in any real sense.

An all-embracing transformative theory of justice that encompasses a generic aspiration for post-conflict Liberia, Colombia and Syria is obviously susceptible to the criticism that it paints with a broad brush. Underlying political and economic configurations define likely trajectories of reform, transformation or stagnation. Some environments are simply more conducive to transformation (or sustainable peace, or democracy, or relapse into conflict, for that matter) than others. It matters a great deal if transitional justice actors are trying to catalyse transformative change in a state like Sri Lanka or Colombia, where the state controls the overwhelming majority of the country's territory and political and economic systems retained functionality (this is not to say either state has actually addressed the root causes of their conflicts, but they could) or in a state like the Democratic Republic of Congo or parts of Syria where the writ of the state does not extend beyond the capital and/or sectarian heartlands. For example, civil wars ended in Central America in a region with a history of liberal norms, integrated into the world economy and surrounded by developed states, which obviously offered more potential for sustainable peace, if not transformation, than those in the Horn of Africa. ${ }^{37}$ Efforts at transformation in widely different states after wildly different conflicts are not analogous, or even comparable in most ways. Theories premised on a generic transformative potential cannot disaggregate different benign or malign situations or provide discriminating concepts for how a given state can achieve more equal opportunities or guarantee the provision of social minima. For transformative theories to be credible, they would need to at least minimally understand the differences between various types of post-war state, outline what variables matter to transformation in predictable ways or what common relationships exist between given justice approaches and socio-economic outcomes. Above all, to assess (rather than assume)

37 Mark Peceny and William Stanley, 'The Resolution of Civil Wars in Central America' (2001) 55 International Organization 149. 
transitional justice's effectiveness at catalysing socio-economic transformation, there needs to be some gauge to appraise the degree of difficulty, which will be differentially weighted in different contexts. This has been done elsewhere. For example, UN rule of law promoters acknowledge that in some post-conflict conditions where institutions are weak, resources negligible and the state is dominated by clientelism, neither historical developments nor economic incentives have produced the conditions that would allow 'thick' conceptions of the rule of law to emerge. Thus, any such ambitions should be jettisoned in favour of thinner versions that merely embed initial mechanisms that might or might not lead to the rule of law over time. ${ }^{38}$ However, there is no such willingness in transitional justice's transformative literature to identify how ambition might be adjusted to conditions.

It should be uncontroversial to state that some characteristics of post-conflict ecologies impinge decisively on justice. There are two main types of variable that condition opportunities for transformative justice, namely generic structural conditions and particular conflict legacies. However, given the scope of socio-economic and political factors at play and the tendency of structures and conflict legacies to mutually undermine each other, there will of course be multiple causality - distinguishing the contribution of one from the other verges on the impossible. To begin with the generic conditions, while advocates of transformative justice are adept at identifying the need for structural alterations, they pay strikingly little attention to structural variables that explain the lack of prior and current transformation. The main such variables are state functionality, domestic politics and economics.

\subsection{State Functionality}

The degree of stateness affects a country's ability to provide services effectively, to be accountable to citizens and to respond to needs or changes in expectations, even if a transformative agenda were accepted by key stakeholders. The basic conditions of an effective political order must be in place in order to generate public goods like welfare or education, to redistribute wealth and resources from powerful groups reluctant to part from them in a bid to redress inequalities or to intervene in markets for beneficial development outcomes. The primary condition is the existence of governmental institutions capable of at least minimally

38 Camino Kavanagh and Bruce Jones, Shaky Foundations: An Assessment of the UN's Rule of Law Support Agenda (Center on International Cooperation 2011) 7 and 9. 
exercising authority, formulating and executing policies, appropriating and using revenue in effective budget plans, regulating social relationships and monopolizing violence. Transitional justice must frequently be administered in areas of limited statehood where these conditions do not obtain, though there is a spectrum of declining performance from merely recovering and weak states (characterized by weak authority, social divisions, some breakdown of law and order) on the one hand, to failed states (non-performance of core duties) and collapsed states (dissolution of state institutions) on the other. ${ }^{39}$ De Greiff describes such societies as 'very imperfect worlds'; societies characterized not just by the massive and systematic violation of norms, but by the fact that there are enormous disadvantages implicated in any attempt to enforce compliance against the vested interests of powerful groups in society. ${ }^{40}$ Weak and narrow tax collection, corruption in public services and lack of human resources are typical features of post-conflict states, most notably in Africa, that preclude the immediate realization of basic needs. Many of the transformative ambitions for transitional justice have questionable short- to medium-term applicability to post-conflict states like Angola, that had only one administrator in regions outside the capital ${ }^{41}$ or South Sudan, where nearly half of its civil servants have only a primary-school education. ${ }^{42}$ As Grindle argues, 'Weak or nonexistent institutions, unresponsive decision-making structures, inefficient organizations, and poorly developed human resources are likely to be overwhelmed by all the things that "must be done". 43

Given the chronic logistical difficulties in operating trials, truth commissions and reparations in the developing world (e.g. Liberia, Rwanda, Cambodia) without international transfusions of assistance for a much more limited set of tasks, these difficulties should be readily apparent to transitional justice theorists, but they have largely been glossed over. By

39 Thomas Risse, 'Governance in Areas of Limited Statehood' in Thomas Risse (ed.), Governance Without a State: Policies and Politics in Areas of Limited Statehood (Columbia University Press 2013) 1.

40 Pablo de Greiff, 'Theorizing Transitional Justice' in Melissa Williams, Rosemary Nagy and Jon Elster (eds), Transitional Justice (New York University Press 2012) 31 at 35 .

41 Dorina Bekoe, Implementing Peace Agreements: Lessons from Mozambique, Angola and Liberia (Palgrave Macmillan 2008) 68.

42 Jago Salmon and Catherine Anderson, 'Elites and Statebuilding' in David Chandler and Timothy Sisk (eds), Routledge Handbook of International Statebuilding (Routledge 2013) 42 at 46.

43 Merilee Grindle, 'Good Enough Governance: Poverty Reduction and Reform in Developing Countries' (2004) 17 Governance 525, 543. 
contrast, in more functional states that retain governing capabilities of extraction (taxation) and redistribution (welfare) even in the midst of war, it should be easier to rebuild the state and implement transformative agendas if such a commitment exists. One of the main challenges for transformative theories of transitional justice is to establish an equilibrium between the expectations for change and state capacity to either meet these expectations itself or secure the conditions where private, traditional or informal actors can do so sustainably. Attempts to reduce poverty, provide services and redistribute wealth have failed in far less challenging non-conflict environments.

\subsection{Domestic Politics}

The prospects for transformation will crucially be conditioned by whether the post-conflict government is pacted, revolutionary or externally imposed, or whether the new leader is an incumbent who seeks to conserve the status quo or the reformist heir of a rebel victory. Beyond this, crucial structural issues will shape the likelihood of social reform. If there has been no fundamental alteration in the allocation of power, then that society will prove of limited malleability. The existence of multiparty polyarchy, residual authoritarianism, loose or tightly regulated powersharing, presidentialism or parliamentarism will all condition prospects for redistribution or positive discrimination.

The breadth and fragmentation of the government or ruling coalition and the characteristics of the state's revenue base are probably the most important determinants of transformability. For example, if the ruling coalition enjoys a narrow base of support and unrestricted access to revenue from natural resources, international capital flows or foreign aid, then this inevitably rent-seeking state has less need to respond to citizen demands or to build state-based infrastructure to collect taxes and develop services. By contrast, where revenue is dependent on collection from broad segments of society, the state needs to (re)develop administrative strength and is more likely to respond to citizen demands. ${ }^{44}$ Transformation of society will obviously be affected by whether the state is mediated (where the state rules indirectly through alliance with local elites, often equated with patrimonialism) or unmediated (where state institutions, not local elites, govern the central features of the state and

44 Louis-Alexandre Berg, 'Guns, Laws and Politics: The Political Foundations of Rule of Law and Security Sector Reform' (2012) 4 Hague Journal on the Rule of Law 4, 10-11. 
provide public goods) ${ }^{45}$ but the transitional justice literature has yet to acknowledge this issue, let alone address it. Transformation will also be affected by whether society is divided into well-defined blocs, is ethnically or religiously diverse and whether there is a strong or weak sense of a national public - transitional justice activities that can mobilize support across sectoral groupings of society are more likely to enjoy sub-state legitimacy and government responsiveness.

\subsection{Economics}

The state's economy will inevitably determine prospects for transformation, particularly if, like many post-conflict countries, the country is clustered around the bottom rungs of development indices. The damage war does to economic infrastructure, the contraction of the legal economy and destruction of human and material resources will of course be important, but they interact with existing economic conditions. Opportunities for states that historically can produce surpluses provide a very different arena for transformation than those that have never enjoyed internally generated change that compels greater state social organization. ${ }^{46}$ The institutionalization of any policy requires a significant level of development in order to be effectively implemented. Countries with a per capita income of less than US\$7,000-8,000 have great difficulty in maintaining a state framework to provide services or collect taxes. ${ }^{47}$

Transitional justice will obviously interact differently with states suffering chronic poverty than it will with states with high horizontal inequalities or with states with high-value natural resources, but no-one within the literature has begun to grapple with the difference between these ecologies. It will matter a great deal whether the state suffers from underdevelopment (suggesting inability to reform) or uneven development (suggesting unwillingness to reform). The extent of patrimonialism as manifested in revenue flows to elites will obviously curb the redirection of wealth and opportunity. Inherited debt is a burden neither the state

45 Michael Barnett and Christoph Zürcher, 'The Peacebuilder's Contract: How External Statebuilding Reinforces Weak Statehood' in Roland Paris and Timothy Sisk (eds), The Dilemmas of Statebuilding: Confronting the Contradictions of Postwar Peace Operations (Routledge 2009) 23 at 27.

46 Rod Nixon, 'The Crisis of Governance in New Subsistence States' (2006) 36 Journal of Contemporary Asia 75.

47 Michael Ignatieff, 'Human Rights, Power and the State' in Simon Chesterman, Michael Ignatieff and Ramesh Thakur (eds), Making States Work: State Failure and the Crisis of Governance (UN University Press 2005) 59 at 69. 
nor transitional justice actors has any control over. Conditionalities for repayments to - or relief from - international financial institutions depend on highly regressive poverty reduction strategies that commit states to reforms that might directly contradict transformative agendas. The transformative transitional justice literature has nothing to say about these barriers to transformation, bar an admirable but undifferentiated opposition to global liberalism (see Chapter 4). Finally, states with higher income levels and growing economies enjoy longer peace durations that may allow transformation to be sustained. Higher levels of economic development are consistently associated with greater probability of peace agreement implementation. ${ }^{48}$

\subsection{Specific Post-conflict Variables}

These semi-permanent structural features interact with more proximate conflict-related ones like war legacy, the peace agreement and the presence of peacebuilders. The nature of the war (i.e. conventional, guerrilla, international) is probably less significant than the peace agreement that ends it. The transformative transitional justice literature's neglect of this factor is notable, given that any agenda for reform would inevitably be a product of conflict variables. The intensity, fractionalization and duration of war and the asymmetries of power after it will influence factors like the state's revenue base, the willingness of factions to compromise and all issues of peace agreement implementation in states variously described as 'divided', 'less divided' or 'deeply divided'. So too will the motivations for war, as they influence what the factions believe the state should and should not do. Is the ideology group-based or universal and society-wide? Is it a successful or unsuccessful war for access to existing power structures or secession from them? Is it a war of identity or a war for resources? Prospects for transformation also depend on whether there is a sustainable peace or merely one that is frozen by the presence of peacekeepers. Any endurance of violence challenges the very presuppositions on which theories of justice are predicated. However, such variables find no place in the fourth generation transitional justice literature. Lack of appropriate differentiation inhibits a good understanding of prospects for social change.

Peace agreements are complex arrangements that can be designed through various combinations of possible post-conflict arrangements and

48 Caroline Hartzell and Matthew Hoddie, 'Institutionalizing Peace: Powersharing and Post-Civil War Conflict Management' (2003) 47 American Journal of Political Science 318, 326-30. 
trade-offs. They are probably the most fundamental variable affecting the prospects for transformative transitional justice as they determine the scope and endurance of the peace that is conditio sine qua non for structural change across society. This element is so important that Chapter 3 of this book is dedicated to peace agreements. For now, it will suffice to point out some key conditioning factors they import. Peace will usually be a pacted agreement, but it matters a great deal whether the agreement is merely pacificatory ('conflict settlement' - for example ceasefire, separation of forces, DDR, power-sharing) or is a genuine attempt to deal with root causes ('conflict transformation'). The latter obviously opens more possibilities for transitional justice to work within and emerge from, as does constitutional review to address fundamental questions relating to the constitutive principles of the new order if it accompanies the peace agreements. The specificity of the agreement is important - those that are broad, ambiguous or insufficiently tailored to the context may impose limits on transformation by making every issue a recurrent source of contestation in the long-term, even if they are necessary to protect the positions of leaders within their factions in the short-term. It also matters, of course, whether the agreement is interim or final, whether provisions are implemented or not, and whether or not the potential spoilers have to be coerced by external actors into compliance. Power-sharing is probably the most important element of the peace agreement (again, examined in detail in Chapter 3). It places limits on subsequent political opportunities by privileging some political actors and marginalizing others, providing a stimulus to pursue certain social objectives over others, and making it less costly to pursue those objectives in some ways rather than others. ${ }^{49}$ To the extent that it divides power politically, territorially and economically, the bargain will delineate opportunities for transformative transitional justice, a factor that is compounded by whether power-sharing is a transitional phase or a permanent regime type. The longer-term prospects for transformation depend on whether the agreement allows peace to endure or the main war-time cleavages to remain salient in the post-conflict political arena.

The peacebuilding mission which transitional justice will operate within or alongside (see Chapter 4) is a key element of the local ecology given that it will often assume a direct role in governing or rebuilding the state. Most often this role will be assumed by the UN as primary implementer or formal monitor, but NATO, the OSCE, the African

49 Donald Rothchild and Philip Roeder, 'Power Sharing as an Impediment to Peace and Democracy' in Rothchild and Roeder (eds) (n 24) 29 at 29. 
Union, European Union, regional coalitions or lead states increasingly play significant roles in creating incentives for peace. Though much is made later in this book of the impact of ideology on peacebuilding, it has organizational as well as conceptual foundations. Transitional justice's impact at anything but the most local level will be limited to the extent that the broader peacebuilding missions they are embedded within, or dependent on, have the right mandate and the requisite capacities to implement post-peace reforms. Peacebuilding operations run a spectrum of functional progression from passive observation and inter-positional missions that permit national actors to pursue their own peace unaided through to more coercive peace enforcement missions, more intrusive multidimensional state-building (over half of UN missions do this) and international territorial administration vested with administrative control and/or executive authority. Key factors affecting the success of peacebuilding missions include the degree of financial and political commitment of the international community, the balance between international authority and effective sovereignty of the state in areas like policy, legislation and constitution-drafting, the presence of boots on the ground that can compel spoilers to desist from challenging peace, the mission's time-frame, and the size of the mission relative to the state's population and geographic size. Light footprints almost guarantee light impacts. Above all, a mission's success will depend on the extent to which local leaders are dependent on them to achieve their political aims or for the country to survive. It is in conditions of dependence that international actors will most successfully encourage difficult choices to be made, but where the paradigmatically opposed situation applies in which the international community is wholly dependent on domestic actors to fulfil their mandates, there is a regrettable tendency to kick the reform can down the road indefinitely. A credible theory of transformative transitional justice would need to outline how these dynamics can be harnessed to the extent they are helpful, or mitigated to the extent they are not.

These variables, most of which cannot be manipulated by international or domestic actors who assume responsibility for transitional justice, are not prerequisites whose absence will doom transformative justice. They are, however, facilitative or non-facilitative, severally and in combination making transformative justice more or less feasible. Though most transitional justice theories begin with ringing affirmations that policies must be tailored to local context, almost no effort has been made to systematize the types of context they will confront when they seek to catalyse socio-economic transformation in post-conflict states. Thoms, Ron and Paris argue that '[c]ausal arguments about TJ should be carefully 
delimited by region, time, transition type, level of democracy, institutional capacity and other characteristics', 50 but it is clear that transformative theories of justice have engaged little with these variables. While it is axiomatic that the opportunity for transformation exists on a continuum on which these variables are arranged, Chapter 2 demonstrates that in the literature of the transformative turn all post-conflict ecologies appear as equivalent, flattening the empirical complexity of situations that need to be carefully parsed if key local actors are to be incentivized to participate. This is troubling, given that most qualitative and quantitative studies of where, when and how transitional justice is applied demonstrate that it continues to be shaped less by its own normative influence than by the political context in which it applies, an agent of change but one which is cabined by transitional politics. ${ }^{51}$ Of course, one can argue that a transformative theory is a necessary prelude to more effectively reckoning with individual states, but that transformative theory itself must be shallow and misleading to the extent that it neglects even generic appreciations of how historical contexts, the shape of war and domestic political economies may limit potential for socio-economic transformation. The standard criticisms of the field, i.e. that policy and implementation are too reliant on ahistorical and decontextualized abstract principles ${ }^{52}$ or that its intellectual and normative frame 'floats above in the realm of the transcendent', are never more apparent than in its transformative turn. ${ }^{53}$

\section{OUTLINE OF THE BOOK}

Transformative justice, to the extent it can be achieved, will be an intermestic product of the complex relationships among these general structural variables and particular post-conflict ones. While this book

50 Oskar Thoms, James Ron and Roland Paris, 'State-Level Effects of Transitional Justice: What Do We Know?' (2010) 4 International Journal of Transitional Justice 329, 353.

51 Padraig McAuliffe, 'The Roots of Transitional Accountability: Interrogating the Justice Cascade' (2013) 9 International Journal of Law in Context 106.

52 Laurel Fletcher, Harvey M. Weinstein and Jamie Rowen, 'Context, Timing and the Dynamics of Transitional Justice: A Historical Perspective' (2009) 31 Human Rights Quarterly 163, 208.

53 Rosalind Shaw and Lars Waldorf, 'Introduction: Localizing Transitional Justice' in Rosalind Shaw, Lars Waldorf with Pierre Hazan (eds), Localizing Transitional Justice: Interventions and Priorities After Mass Violence (Stanford University Press 2010) 3 at 4. 
concentrates more on the post-conflict factors than the structural ones, it argues that states vary so much in terms of economics, politics and socio-cultural qualities that it is unwise and infeasible to assume a priori that transitional justice can have even minimal transformative effect. Instead, policy-makers and actors within the field should systematically analyse the conditions under which different approaches can succeed. This is not to argue that only context-specific empirical analysis is useful or that there is no place for theory. However, there needs to be a less scattergun assessment of the relationship between transformative norms and the politics, economics or culture of the state, and careful attention to war-time legacies, the parameters of the peace agreement and the degree of international involvement as the points of departure.

In exploring how this might be done, the book departs from a trend visible in most transitional justice theorization, which is to start from the position our (theorists, policy-makers, practitioners) implicit politics of justice - be they liberal-legalist, restorative, entirely deferential to local preference or transformative. Instead, it adopts an 'inside-out' approach, eschewing a focus on the values, biases and motivations of transitional justice actors and how this leads to the prioritization or marginalization of certain values in order to concentrate on the social and political power relationships and structures within the state that these actors must interact with - and must be shaped by. The 'inside-out, outside-in' language is adapted from Shahar Hameiri's Regulating Statehood. ${ }^{54}$ While Hameiri's focus and conclusions differ in many critical respects to those of this book, I share his concern that the outside-in perspectives so common in critical peacebuilding discourse (not to mention transitional justice) mean that intervention is always seen as the imposition of external actors on essentially passive locals and explained in ideological/ideational terms. The resulting scholarly debate creates the misleading impression that intervention 'is essentially a struggle between competing and generally coherent paradigms of "liberal" and "non-liberal" peace, institutions and values', when the reality is much messier and more contested. 55 Outside-in analysis, by contrast, is directed less towards actual postconflict or statebuilding ecologies than towards the static dichotomies that obsess theorists of transitional justice: international - local, state -

54 Shahar Hameiri, Regulating Statehood: State Building and the Transformation of the Global Order (Palgrave Macmillan 2010) 26.

55 Shahar Hameiri, 'A Reality Check for the Critique of the Liberal Peace' (2011) in Susanna Campbell and David Chandler (eds), A Liberal Peace? The Problems and Practices of Peacebuilding (Zed Books 2011) 191 at 197. 
society, formal - informal, liberal - transformative. ${ }^{56}$ It is more productive to look at interventions like transitional justice in terms of other regimes within the state that it interacts with and that have their own sources of power and legitimacy. These are factors worthy of explanation in their own right, as distinct from a focus on transitional justice as an avatar of a liberal-legalist ideology that in practice is mediated beyond recognition by its interaction with the post-conflict ecology. Transitional justice theorizing is so busy imagining where justice should go that it neglects to consider where it begins - an inside-out view means starting from the point of transition within the state, and not with our own conceptions of justice from outside it. As such, it requires the state to be considered as a site of social and political conflict.

Chapter 2 explores transitional justice's transformative turn. It examines the social constructivist notion that the discourse adopted within transitional justice establishes the bounds of what projects can be pursued. Policy-makers focus more on the end-goal of transformation ('the why') than they do on the policy-making and implementation aspects of this aspiration ('the how'). After this, this book examines these policy-making and implementation aspects under three distinct concepts:

1. It considers the prospects for transformative transitional justice within the political economy of a post-conflict peace agreement (Chapter 3).

2. It considers the prospects for transformative transitional justice within the context of a peacebuilding mission (Chapter 4).

3. It considers the prospects for transformative transitional justice within the geography of the post-conflict ecology - to what extent can top-down and bottom-up conceptions of transformation be reconciled? (Chapter 5)

\subsection{Transitional Justice within the Political Economy of a Post-conflict Peace Agreement}

As Chapter 2 goes on to argue in greater detail, peace, like any other significant political transition, is seen within the transitional justice literature as a window of opportunity. As the OHCHR notes, transitional justice 'is built on the assumption that social, economic and political changes are possible when significant negotiations of power are taking

56 Hameiri, Regulating Statehood (n 54) 11 and 31. 
place in a state' 57 Peace agreements are seen as progressive, problemsolving institutions concerned with achieving normative goals. Peace agreements typically include human rights provisions, which open up the potential for a 'just peace' where humanitarian law, international law and human rights law create ideal demands. However, this vision of the normatively-infused just peace is but one normative frame. The other is a conflict management imperative which sees the onus to end conflict as the essential, and sometimes exclusive, objective of peace. For reasons that Chapter 3 examines in depth, the tension between conflict management in the short-term and more long-term normative objectives indispensable for a 'just' sustainable peace is generally resolved in favour of the former, largely as a result of internal dynamics but with the acquiescence of peacebuilders. Peace agreements are only ever concluded between belligerents with strong contrasting views as to what norms are important and what the content of those norms should be. The selfinterest of those who wish to consolidate the gains of war-time economies and general concern for security often precludes detailed schemes for human rights, constitutionalization of structural reform or the participation of the voices of civil society or the most marginalized citizens. There is also a strong element of dividing the spoils, sometimes as a necessary adjunct to security but sometimes from more acquisitive motivations, which tends to preclude the use of those resources for social inclusion or equitable development. Power-sharing often transmutes military stalemate into political stalemate. Groups who did not take up arms - such as women, the urban poor and other minority groups seldom have a voice in shaping agreements. Consequently, peace agreements revolve around give-and-take bargains struck by antagonists instead of shared holistic, rational political visions.

It is in this environment that transitional justice must be considered. Strategic options that are theoretically available to transitional justice implementers may not be 'incentive compatible' in as much as they are not in the rational self-interest of critical, politically effective groups (the government, faction leaders and other elites, for the most part) to adopt, as they may contradict the bargains reached to agree the peace, or appear entirely tangential to them. For this reason, much of the critique of liberal peace interventions is premised on the argument that they are 'so heavily biased towards institutions and the elites that control, hijack, or co-opt

57 Office of the High Commissioner for Human Rights 'Transitional Justice and Economic, Social and Cultural Rights' (2014) $6<$ http://www.ohchr.org/ Documents/Publications/HR-PUB-13-05.pdf> accessed 20 July 2016. 
them that it undermines the very capacity of individuals in political, social, and economic spheres of life that it is supposed to promote'. ${ }^{58}$ This has fed the transformative critique of transitional justice, which is seen to be actively perpetuating the position of existing economic elites instead of empowering the marginalized. ${ }^{59}$ This position assumes that there is an alternative to dealing with elites, but it is one which a greater familiarity with the means by which peace is negotiated would call into question. Chapter 3 argues that transitional justice can only ever be the product of the dynamic interaction between internal and external transitional justice actors, on the one hand, and critical internal political actors whose commitment to these outcomes is indispensable and who retain capacity to resist or 'spoil' them, on the other. Transitional justice actors attempt to deliver broadly understood concepts of justice, while political elites accept, acquiesce or reject various outcomes depending on their own post-conflict interests and identities. The peace agreement, therefore, should be treated as a 'hard constraint' on transformation - without significant domestic impetus to alter the structures of society, we should be extremely cautious about expecting internal or external transitional justice actors to catalyse reform. The question is not what type of justice we wish to achieve, but rather what kind of generally acceptable structural transformation can occur in a particular country, based on present power distribution, countervailing forces that may arise with some encouragement and help, and the level of external support that can be mobilized for the particular country. ${ }^{60}$

\subsection{Transformative Transitional Justice within the Context of a Peacebuilding Mission}

Beyond the peace agreement, transitional justice in any post-conflict state will generally occur within, alongside or in the shadow of parallel peacebuilding missions. Even to the extent that transitional justice activities occur independently of peacebuilding missions (a rarity given how embedded transitional justice is within such missions and the

58 Roger Mac Ginty and Oliver Richmond, 'Myth or Reality: Opposing Views on the Liberal Peace and Post-war Reconstruction' (2007) 21 Global Society 491, 493.

59 Aguirre and Pietropaoli (n 34) 367.

60 To paraphrase Marina Ottaway, 'Promoting Democracy After Conflict: The Difficult Choices' (2003) 4 International Studies Perspectives 314, 321. 
evident difficulty of conducting trials, truth commissions, vetting, constitutional reform or reparations without international donors or supranational help), its prospects and sustainability will be conditioned by the success of peacebuilding. However, theorization about the capacity of transitional justice to transform socio-economic arrangements has proceeded largely without any reference to peacebuilding, or any of the factors that condition the malleability of the structures of the state peacebuilders work with - military balances, spoilers, the state's administrative capacity, and so forth. As both Lambourne and Andrieu note, the research focus of transitional justice is rarely situated in a peacebuilding context. ${ }^{61}$ This neglect is not entirely surprising. Observers note a tendency in transitional justice 'to reinvent the wheel - to believe that transitional moments require new or exceptional responses when more established disciplines have long wrestled with similar problems ... [it] has often paid insufficient attention to what has already been written on these recurrent themes'.62

Even the elementary work of distinguishing transitional justice in the peacebuilding context from that of post-authoritarian democracy-building has yet to be done, ${ }^{63}$ though it is hoped that this book will make such a contribution. Much has been made of the way transitional justice has embraced, and been embraced by, other disciplines like anthropology, development studies, feminist studies and sociology. As Chapter 2 goes on to explore, the increasingly interdisciplinary nature of transitional justice has led to an expansion of the claims made regarding how society can be transformed. It is unfortunate that peacebuilding, a field of study that is profoundly more pessimistic about the malleability of post-conflict societies and with expectations that are much narrower than the basket of goods associated with the transformative turn, has not been embraced with the same alacrity. Indeed, one explanation offered for transitional justice's failure to penetrate the dominant logics of peacebuilding in any

61 Wendy Lambourne, 'Transformative Justice, Reconciliation and Peacebuilding' in Susanne Buckley-Zistel et al. (eds), Transitional Justice Theories (Routledge 2013) 19 at 19; Kora Andrieu, 'Civilizing Peacebuilding: Transitional Justice, Civil Society and the Liberal Paradigm' (2010) 41 Security Dialogue 537, 539.

62 Phil Clark and Nicola Palmer, 'Challenging Transitional Justice' in Nicola Palmer, Phil Clark and Danielle Granville (eds), Critical Perspectives in Transitional Justice (Intersentia 2012) 1 at 4.

63 Paige Arthur, 'How "Transitions" Reshaped Human Rights: A Conceptual History of Transitional Justice' (2009) 31 Human Rights Quarterly 321, 360; Dustin Sharp, 'Emancipating Transitional Justice from the Bonds of the Paradigmatic Transition' (2014) 9 International Journal of Transitional Justice 150, 151. 
meaningful way is that considerations of stability that lie at the root of peacebuilding are more often considered to be at odds with justice, and not a necessary complement to it. ${ }^{64}$

Better understanding of peacebuilding is crucial because it guides all thinking and activity by other intervening actors. The manner in which peacebuilders try to augment and capitalize upon domestic processes of transition to alter the incentives of post-conflict elites to address basic human needs is something the transformative turn can learn from, particularly when we consider that some of the more expansive conceptions of transformative transitional justice replicate peacebuilding in a one-to-one facsimile.65 Some generalization about the prospects for wide-ranging transitional justice is possible from within the peacebuilding literature as it attempts to reduce the mismatch between the domestic context and the hopes that are attached to it internationally. For example, Doyle and Sambanis differentiate among post-conflict ecologies and find that external interventions are more likely to be successful where local capacities are reasonably high and post-conflict context is less hostile, and less so where these conditions are reversed, but that international assistance can compensate for weak capacity and deep hostility. ${ }^{66}$ Zurcher, Manning and Everson argue that all post-conflict projects depend significantly, though not exclusively, on the incentives facing domestic actors. That is, any co-operative peace process (like transitional justice, though the authors' focus is democratization) is most likely to succeed when interveners exercise a high degree of leverage over domestic political actors and when these actors perceive the costs of prescribed reforms to be low. ${ }^{67}$ Reychsler and Langer outline a four-fold framework for understanding the potential for successful peacebuilding around four variables: difficulty of the conflict ecology, internal and external peacebuilding willingness and capacity, the architecture of the peace process overall and the success of the parallel peace process. ${ }^{68}$

64 Chandra Lekha Sriram, 'Justice as Peace? Liberal Peacebuilding and Strategies of Transitional Justice' (2007) 21 Global Society 579, 583.

65 See for example the 'thick' conception of transitional justice in Sarah Maddison and Laura Shepherd, 'Peacebuilding and the Postcolonial Politics of Transitional Justice' (2014) 2 Peacebuilding 253, 259.

66 Michael Doyle and Nicholas Sambanis, Making War and Building Peace:

United Nations Peace Operations (Princeton University Press 2006) 4.

67 Zürcher, Manning and Evenson (n 23) 28.

68 Luc Reychler and Arnim Langer, Researching Peace Building Architecture

(Centrum voor Vredesonderzoek en Strategische 2006) 48. 
However, transitional justice theory takes place devoid of any such generalized analysis of opportunity structures.

If the transitional justice literature was more aware of peacebuilding, it would become apparent that few within the field share transitional justice's transformative optimism. Though much is made of the inherent liberalism of peacebuilding, it is clear that the UN's ultimate purpose in all peace missions is what it labels 'sustainable peace' (defined as the capacity of conflict parties to move political or economic struggles from the battlefield and into an institutional framework where disputes can be resolved), ${ }^{69}$ a goal which falls a good deal short of the ambitions of the transformative turn. Though the UN's rhetoric of democracy and human rights is condemned in the critical peacebuilding and transitional justice literatures as insufficiently ambitious, a quarter-century of modern peacebuilding in the likes of East Timor, Bosnia, Rwanda and Libya make clear that international interveners are seldom capable of achieving any ambition beyond negative peace in anywhere but the most benign conditions. There has been a significant lowering of expectations that peacebuilders can socially engineer any outcome that is not already supported by domestic power elites who generally tend to benefit from systematically unequal structures. Some concede that elite dominance of society is unavoidable, and that the best that may be hoped for is that the elites prefer long-term stability and state-building to short-term partisan advantage. ${ }^{70}$ Others counsel that the idea of reconstructing society is unrealistic and recommend a more minimalist 'security-keeping' approach that ends fighting and restores basic security rather than attempting to build any kind of political or economic metamorphosis. ${ }^{71}$ Even those who argue that governance should be directed primarily towards development and poverty reduction accept a need for honest acknowledgement of how institutional capabilities evolve and the tradeoffs that inevitably must be made. The best that can be achieved may merely amount to 'good enough governance', a minimally acceptable government performance that does not dramatically hinder development and allows poverty reduction initiatives to proceed even if more

69 UN Secretary-General, No Exit without Strategy: Security Council Decision-making and the Closure or Transaction of United Nations Peacekeeping Operations, Security Council UN Doc. S/2001/39 of 20 April 2001, para. 10.

70 Andrew Reynolds, 'Constitutional Medicine' (2005) 16 Journal of Democracy 54,65 .

71 Kimberly Zisk Marten, Enforcing the Peace: Learning from the Imperial Past (Columbia University Press 2004) 19. 
ambitious output benchmarks go unrealized. ${ }^{72}$ Similarly, state-building theorists remind us that the weaker and more fragile the country, the less sense it makes to evaluate governance services with reference to benchmarks derived from more developed states. ${ }^{73}$ A country like El Salvador, where there is chronic criminal violence and widespread horizontal inequalities between the 'haves' and the 'have-nots', would appear the epitome of injustice in the transformative transitional justice literature, but is regarded as a success among peacebuilders. ${ }^{74}$

One of the key questions this book addresses is whether this attitude is the product of a liberal unconcern for structural injustice or a sober recognition of the limited malleability of such states. This brings us to the one exception to transitional justice's overall lack of awareness of peacebuilding, namely the general incorporation of a liberal peacebuilding critique into transformative theorizing. This critique argues that liberal peacebuilding's standard package of elections, rule of law and state-building, in which liberal democracy and market economics represent the most efficacious route to peace, excludes the key problems of redistribution and equality. As such, liberal intervention typically discounts (implicitly or explicitly) wider conceptions of democracy that would incorporate greater socio-economic participation premised less on individual freedom than on collective goods and reducing extant inequalities. Modern peacebuilding is seen as alien to the extent it attempts to impose democratic and market-based solutions, securitized to the extent that it merely attempts to contain conflict in the interests of the Global North's ease of exploitation, and conservative to the extent that these approaches preclude transforming conflicts by critically examining their basis. Transitional justice, rooted in post-authoritarian transitions to Westernized liberal market democracy, remains trapped in this liberal paradigm..$^{75}$ Transitional justice's neglect of maldistribution and poverty, therefore, is regarded as a deliberate choice, a 'constructed invisibility'

\footnotetext{
72 Grindle (n 43).

73 Risse (n 39) 17.

74 Chandra Lekha Sriram, Peace as Governance: Power-sharing, Armed Groups, and Contemporary Peace Negotiations (Palgrave Macmillan 2008) 45-47.

75 Kris Brown and Fionnuala Ní Aoláin, 'Through the Looking Glass: Transitional Justice Futures through the Lens of Nationalism, Feminism and Transformative Change' (2015) 9 International Journal of Transitional Justice 127, 137.
} 
within the liberal-legalist schema of modern human rights discourse. ${ }^{76}$ Sharp, for example, argues that transitional justice is so enmeshed in liberal peacebuilding schematics of democracy and the market economy that the issues of social justice that cause, exacerbate and flow from conflict go unnoticed. With this invisibility removed, he argues, transitional justice's emancipatory potential can be realized - a more holistic analysis of the drivers of conflict and capital can be marshalled to effect positive peace in the wake of conflict. ${ }^{77}$

Chapter 4 examines the impact of the liberalizing imperatives of transitional justice, but questions the taken-for-granted assumptions which underlie much of this critique. Above all, it asks the key question of how much influence exogenous transitional actors who are based temporarily in the state with limited resources and relatively shallow commitment actually exercise on post-conflict outcomes against endogenous actors, permanently based and, as the sheer fact of conflict demonstrates, keenly motivated. The success of transitional justice, no less than peacebuilding as a whole, is defined by the strategic interactions of international and domestic justice actors with critical domestic elites who largely dictate political and economic decision-making. ${ }^{78}$ The resulting bargaining process is the best indicator of the prospects for peace. The international community is, at best, the facilitator of peace, but certainly not the engineer of it. As Torjesen argues, reflecting on the historical record of liberal post-conflict interventions, "It is unlikely that outside initiatives can "impose" themselves on post-war societies and autonomously direct the process of transformation from war to peace'. ${ }^{79}$

\subsection{Transitional Justice at Micro and Macro Levels}

Of course, not all transitional justice is externally directed by the international community or those international NGOs that import comparative knowledge and mobile expertise to transitional states, and not all of it is located at state level. As Chapter 5 examines, transitional justice scholars increasingly emphasize the indispensability of what is variously

\footnotetext{
76 Zinaida Miller, "Effects of Invisibility: In Search of the "Economic" in Transitional Justice' (2008) 2 International Journal of Transitional Justice 266.

77 Dustin Sharp, 'Introduction: Addressing Economic Violence in Transition' in Sharp (ed.) (n 6) 1 at 19.

78 Barnett and Zürcher (n 45).

79 Stina Torjesen, 'Transition from War to Peace: Stratification, Inequality and Post-war Economic Reconstruction' in Berdal and Zaum (eds) (n 33) 48 at 60 .
} 
described as local, bottom-up, micro-level and grassroots forms of justice that emerge from indigenous/traditional conceptions of justice or ad hoc forms of civil society-derived justice. Some even argue that bottom-up forms of justice should replace top-down, statist iterations of transitional justice like trials, truth commissions and national reparations programmes. Much of this emphasis stems from the normative propositions that localized forms of justice are more legitimate, more participatory and accord better with prevailing social norms in the locale. As such, they consciously depart from a previous preference for formal, national and international institutions at the expense of communities and individuals who actually engage in the everyday practices of peace and justice. This emphasis also stems from a transformative impulse flowing from an apparently widely shared faith that fruitful local initiatives can inculcate principles of peace, development and harmony beyond the immediate community and so contribute to restructuring broader social arrangements. ${ }^{80}$ An emergent literature posits links between local justice and transformation on the basis that the former can outline the co-existence and legitimacy of multiple social meanings or can open critical space to redefine the social meaning of the good. Because grassroots approaches are informed by the local and particular needs of survivor communities, they increase the legitimacy of the demands of those involved and encourage micro-level actors to be more proactive in the process of social reconstruction. ${ }^{81}$ It is assumed that localized justice projects will promote needs-based agendas and welfare, and that this feeds upwards into wider demand for reform by substantiating or catalysing civil society movements. ${ }^{82}$ Localized forms of justice operated by non-state actors and civil society are presented as resistant to hegemonic social, political and economic forces that underpin poverty and structural inequality ${ }^{83}$

The book examines the potential and limitations of grassroots approaches to justice to deal with underdevelopment and distributive

80 Kora Andrieu, 'Civilizing Peacebuilding: Transitional Justice, Civil Society and the Liberal Paradigm' (2010) 41 Security Dialogue 537, 545 and 547.

81 Patricia Lundy and Mark McGovern, 'Community, Truth-Recovery and Conflict Transformation "From Below" in Libby Chapman et al. (eds), A Sustainable Peace? Research as a Contribution to Peace-Building in Northern Ireland (Community Relations Council 2008) 155.

82 Paul Gready and Simon Robins, 'From Transitional to Transformative Justice: A New Agenda for Practice' (2014) 8 International Journal of Transitional Justice 339, 349.

83 Chandra Lekha Sriram, 'Post-Conflict Justice and Hybridity in Peacebuilding' in Oliver Richmond and Audra Mitchell (eds), Hybrid Forms of Peace: From Everyday Agency to Post-Liberalism (Palgrave Macmillan 2012) 58. 
injustices both within the community and in the post-conflict state at large. It argues that prevailing theories about the merits of bottom-up justice, which again take their starting point as our views of justice and our blindspots, are insufficiently grounded in analysis of how these communities are positioned within a post-conflict state. Though scholars in the area are commendably supportive of grassroots initiatives, the discourse has been far more about advocacy of community-led and participatory projects than establishment of causal relationships between these approaches and broader socio-economic structures. Little effort has been expended in the transitional justice literature to unpack the interactions between bottom-up processes centred on small-scale communities and individual relationships, on the one hand, and top-down dynamics that revolve around major, state-wide institutions and relationships. The assumption that changes in individual or small-group attitudes or behaviours induced by localized justice processes can eventually impact on surrounding socio-economic structures ignores a consensus among peacebuilding scholars that while citizen-driven, communitybased processes can bridge social divides in communities, they seldom move beyond the local level. As one of the more forceful advocates of deference to local solutions to issues of peace and justice admits, '[i]n many cases the indigenous and traditional approaches are merely containment strategies that, while local and sustainable, do not have the potential to transform conflicts by critically examining their basis' ${ }^{84}$ Most scholars and practitioners of peacebuilding are therefore agreed that local approaches to peace and development cannot succeed without the state (and vice versa). If we take structural inequality and poverty seriously as collective action problems, the legitimate use of the state's administrative capacity and coercive power to extract taxes and resources is needed to lead social allies like rural or urban communities to execute an effective development or redistributive project.

While most peacebuilding theorists welcome grassroots processes, they consistently maintain that prospects for peace or justice cannot be fully understood by analysing the local alone, and so promote systematic approaches that understand localized processes as elements of an interrelated whole. ${ }^{85}$ However, the bottom-up discourse in what I call transitional justice's 'local turn' evinces little interest in exploring systematic approaches. The emphasis on reconciliation within and between

84 Roger Mac Ginty, International Peacebuilding and Local Resistance: Hybrid Forms of Peace (Palgrave Macmillan 2011) 52.

85 Andries Odendaal, A Crucial Link: Local Peace Committees and National Peacebuilding (US Institute of Peace Press 2013). 
communities cannot incorporate wider, state-driven geographies of inequality. The often anti-statist discourse of bottom-up justice rhetorically and organizationally pulls in distinctly different directions to top-down generation of public goods like welfare or education, the redistribution of wealth from powerful groups, or state intervention in markets to promote beneficial development outcomes.

\section{CONCLUSION}

The book essentially argues something simple - that domestic structural conditions and the domestic vicissitudes of peace-making weigh heavily in shaping justice outcomes to a degree that transformative theories of transitional justice have insufficiently acknowledged. The substantive commitments and institutional forms of socio-economic justice cannot simply be dropped into a given post-conflict state; they must be imbricated in its political, economic and social frameworks. In post-conflict states these networks are contested, and the means by which these contests occur tend to be less authoritative and more fragmented than the transformative turn appears to appreciate. The malleability of postconflict society will be conditioned by fundamental characteristics of culture, history, agency, fortuna and intervention that do not depend on and can only be minimally affected by - transitional justice projects. The book starts, therefore, from the position of transition, not justice. This book argues that transitional justice scholars should begin not from what the ideal transformative end-goal would look like, but from what can realistically be achieved over time based on the post-conflict distribution of power, the capacity of the state concerned, the resources available to transitional justice actors and other interveners, and the likely opposition of forces who stand to lose from redistribution, equality or structural reform. Prescriptions for what transitional justice should achieve in a given context would be more helpful if they were based on a clear understanding that these societies are not blank canvases awaiting the introduction of more holistic or transformative conceptions of justice than hitherto practised, but political systems with distinct dynamics which may or may not militate in favour of transformation. The direction of transitional justice energies should be determined by attainable objectives, not pre-fabricated goals. The book outlines the scope conditions for success or failure of transformative approaches to transitional justice. It squarely faces the likelihood that any attempt to catalyse transformation by building on domestic social forces, even where substantial, is unlikely to follow a linear trajectory. I do not argue that transitional justice is 
subsumed in its entirety into politics as usual, but it cannot be wholly abstracted from them. In all probability, any attempted transformation is instead likely to generate opposition that transitional justice actors cannot face down, and dilemmas they cannot resolve but (perhaps) only manage. In many cases, no more than minimal improvement is likely to follow.

The linkage between transitional justice and socio-economic outcomes is inevitably complex. For donors, NGOs and actors on the ground, a deeper understanding of how their programmes are affected by broader political and economic currents is necessary as our knowledge of why transformative outcomes are so difficult to achieve is underdeveloped. Though extremely ambitious in its aspirations, theorization in transitional justice is seldom able to answer basic policy-related questions regarding 'what works'. This means that the contribution of scholarship in the field to programmes on the ground that attempt to revise structural inequalities may be limited. It needs to develop more contingent and context-specific understandings if it is to more capably contribute to transformation of social structures. This book proposes that transitional justice needs to be seen in the broader context of the contingent, dynamic and historicallyinformed process of peacebuilding. In so doing, it purposefully integrates pertinent literatures like war studies, conflict settlement, peacebuilding and war recurrence that rarely serve as building blocks for policy reflection in the field's analytic mainstream.

Above all, the inside-out approach shifts the analytical focus from one that concentrates primarily on the ideology and behaviour of transitional justice actors (i.e. the liberalism that supposedly contaminates theory and practice) to the agency, interests and power of national actors elevated to key positions by the vagaries of conflict and its resolution. In a field characterized like so much of human rights-based scholarship by 'faithbased' over 'fact-based' prescriptions, ${ }^{86}$ this book can therefore be seen as a path-clearing exercise to make a constantly expanding and inchoate realm of theory more manageable. It may help to refine our ability to comprehend transitional justice developments in post-conflict states. Although this chapter has drawn attention to the many variables that will affect the prospects for transformative peace, it cannot address them all in sufficient depth. Greater attention is given to proximate post-conflict variables than permanent features of the state's functionality and economy, where only the surfaces of these phenomena can be scratched. Nevertheless, understanding this post-conflict paradigm may permit more focused analysis than a generalized transitional justice discourse on

86 Clark and Palmer (n 62) 5. 
socio-economic transformation which eschews any effort to define what types of transition it refers to, and it might also permit wider generalizations beyond a particular state. Much of the learning experience in transitional justice is derived from sui generis individual states or localities, but there are obvious advantages to complementing this with general, transferable knowledge about the properties of post-conflict states and their interaction with other factors.

Transformative justice is inspirational as a transcendent abstraction, but identifying its implications in terms of the production, distribution and reproduction of power within the polity renders it more fallible than the rhetoric would suggest. The record of transitional justice in catalysing even minor change to socio-economic conditions is patchy at best, calling for greater humility and realism than is evident in Chapter 2's survey of the literature. Even if we accept that external actors can shape some outcomes in post-conflict states, there are pre-constituted, historical relations of political power and state capacity that interact with more proximate realities stemming from conflict that cannot be presumed to be more than minimally malleable. This book broadens the analytical focus of the transformative transitional justice literature from needs to opportunity to help appreciate the complexity and messiness of possible transformation. The approach is descriptive in attempting to recognize the processes that generate different outcomes, as opposed to normative in prescribing outcomes. The aspiration is not a general theory of transformative justice, but rather some mid-level theories that can explore how post-conflict ecologies emerge, what political economies they typically generate, and why these might or might not conduce to structural transformation. Some things are worth studying in order to understand how they can be overcome; other things are worth studying to understand how difficult they are to change. 